\title{
PENGELOLAAN DEFISIT NUTRISI PADA BAYI DENGAN MALNUTRISI DI DESA MRANGGEN KIDUL
}

\author{
The Management of a Nutrition Deficit in Babies with Malnutrition in Mranggen Kidul \\ Village
}

\author{
Isma Ulia ${ }^{1}$, Siti Haryani ${ }^{2}$ \\ 1. Mahasiswa Prodi D3 Keperawatan Fakultas Kesehatan Universitas Ngudi Waluyo \\ 2. Dosen Prodi D3 Keperawatan Fakultas Kesehatan Universitas Ngudi Waluyo
}

\section{Riwayat artikel}

Diajukan: 2 Agustus 2021

Diterima: 1 September

2021

\section{Penulis Korespondensi:}

- Isma Ulia

- Mahasiswa Prodi D3

Keperawatan Fakultas

Kesehatan Universitas

Ngudi Waluyo

e-mail:

uliaisma@gmail.com

\section{Kata Kunci:}

Malnutrisi, Defisit Nutrisi, Bayi

\begin{abstract}
Abstrak
Pendahuluan: Malnutrisi banyak ditemukan pada bayi dengan usia diatas 6 bulan dikarenakan banyak keluarga yang belum memahami kebutuhan bayi secara khusus, belum mengerti cara membuat makanan pendamping yang bernutrisi sehingga menyebabkan bayi mengalami penurunan berat badan. Penurunan berat badan ini diakibatkan karena adanya gangguan dalam penyerapan makanan, sehingga terjadi defisit nutrisi Defisit nutrisi merupakan keadaan dimana asupan nutrisi tidak cukup untuk metabolisme tubuh Tujuan Penulisan ini bertujuan untuk memberikan deskripsi atau gambaran tentang pengelolaan defisit nutrisi pada bayi dengan malnutrisi di Desa Mranggen Kidul. MetodeJenis penelitian deskriptif dengan pendekatan asuhan keperawatan berupa pengkajian, analisis data, merumuskan diagnosa keperawatan, perencanaan, pelaksanaan, dan evaluasi dalam penanganan malnutrisi. Waktu yang dilakukan selama pengelolaan asuhan keperawatan ini yaitu 5 x 24 jam dengan jumlah responden 1. Karakterisitik responden tersebut yaitu bayi dengan usia 0-12 bulan, bayi yang mengalami malnutrisi, dan memiliki kesadaran composmentis. Hasil: Didapatkan hasil selama melakukan asuhan keperawatan berat badan pasien mengalami penambahan 0,1 kg yang awalnya 5,0 menjadi 5,1 kg dan status nutris pasien (BB/U: -4,3 SD (gizi buruk), PB/U: -4,1 SD (sangat pendek), BB/PB: -3,6 SD (sangat kurus), IMT/U: -3,7 SD (sangat kurus)). Berdasarkan hasil tersebut dapat disimpulkan bahwa malnutrisi pada pasien belum teratasi dikarenakan berat badan pasien masih dibawah normal berat badan usia bayi 11 bulan. Kesimpulan: Saran bagi keluarga agar lebih memperhatikan dan mengetahui bagaimana cara penanganan malnutrisi pada bayi.
\end{abstract}

\section{Abstract}

Background: Malnutrition is often found in infants aged over 6 months because many families do not understand the baby's specific needs, do not understand how to make nutritious complementary foods, causing babies to lose weight. This weight loss is caused by a disturbance in the absorption of food, resulting in a nutritional deficit. Objective: This paper aims to provide a description or description of the management of nutritional deficits in malnourished infants in Mranggen Kidul Village .Method : This type of descriptive research with nursing care approach in the form of assessment, data analysis, formulating nursing diagnoses, planning, implementation, and evaluation in the handling of malnutrition. The time taken during the management of nursing care is $5 \times 24$ hours with the number of respondents 1. The characteristics of these respondents are infants aged 0-12 months, infants who are malnourished, and have composmentis awareness. Results : The results obtained during nursing care that the patient's weight increased by $0.1 \mathrm{~kg}$ from 5.0 to $5.1 \mathrm{~kg}$ and the patient's nutritional status (BB/U: $-4.3 \mathrm{SD}$ (poor nutrition), $P B / U:-44.1 S D$ (very short), BW/PB: -3.6 SD (very thin), BMI/U: $-3.7 S D$ (very thin)). Based on these results, it can be concluded that malnutrition in the patient has not been resolved because the patient's weight is still below the normal weight of an 11-month-old baby. Conclusion: Suggestions for families to pay more attention and know how to handle malnutrition in infants. 


\section{PENDAHULUAN}

Menurut Diah (dalam Sampul et al., 2015), malnutrisi yaitu penyakit dengan kekurangan energi protein dan defisiensi malnutrisi yang membutuhkan perhatian khusus terutama di negara-negara berkembang. Malnutrisi banyak ditemukan pada bayi usia diatas 6 bulan dikarenakan banyak keluarga yang belum mengerti kebutuhan bayi secara khusus, belum mengerti cara membuat makan pendamping dan sapihan dari bahanbahanyang bernutrisi (Rahim, 2014).

United Nations Chilndern's Fund (UNICEF) indonesia mengatakan tanpa adanya tindakan yang memadai dan tepat waktu, jumlah anak yang mengalami kekurangan gizi diperkirakan akan meningkat sebesar $15 \%$ atau 7 juta di seluruh dunia pada tahun pertama pandemi Covid-19 ini (Litha, 2020). Menurut UNICEF (dalam Hanifah et al., 2019), pada tahun 2017 di dunia balita yang mengalami stunting sebesar $22 \%$ atau 151 juta dan balita yang mengalami wasting sebesar $7,5 \%$ atau 51 juta dari penduduk yang ada di dunia.

Di indonesia balita yang mengalami gizi buruk (malnutrisi) pada tahun 2018 yaitu sebesar 3,9\% (Napu, 2019). Pada tahun 2018 presentase balita usia 0-59 bulan yang mengalami gizi buruk di Jawa Tengah yaitu 3,7\% Riskesdas (dalam Dinas Kesehatan Jawa Tengah, 2019). Pada tahun 2018 balita yang mengalami gizi buruk berdasarkan jenis kelamin laki-laki di Kabupaten Temanggung yaitu sebanyak 16 orang (Dinas Kesehatan Temanggung, 2018). Berdasarkan data laporan gizi di Puskesmas Bansari didapatkan jumlah balita yang mengalami gizi buruk dengan indeks BB/TB pada tahun 2021 yaitu 1 orang.

Faktor penyebab gizi buruk dapat dilihat dari penyebab langsung dan tidak langsung (Sholikah et al., 2017). Penyebab langsung gizi buruk yaitu kurangnya jumlah dan kualitas makanan yang dikunsumsi dan menderita penyakit infeksi. Sedangkan penyebab tidak langsung gizi buruk yaitu ketersediaan pangan rumah tangga, kemiskinan, pola asuh kurang memadai dan pendidikan yang rendah (Oktavia et al., 2017).

Asupan nutrisi yang tidak terpenuhi dengan baik bisa berakibat pada keberlangsungan sistem tubuh apabila tidak ditangani dengan cepat makan akan menyebabkan balita mengalami penurunan berat badan (BB), mukosa bibir kering, cepat kenyang setelah makan dan nafsu makan balita menurun. Defisit nutrisi merupakan asupan nutrisi yang tidak cukup untuk memenuhi kebutuhan metabolisme tubuh (Tim Pokja SDKI DPP PPNI, 2016). Penatalaksanaan keperawatan dalam menangani malnutrisi dapat dilakukan dengan pemberian Air Susu Ibu (ASI) dan Makanan Pendamping ASI (MP-ASI).

Berdasarkan masalah di atas penulis tertarik untuk melakukan pengelolaan defisit nutrisi pada bayi dengan malnutrisi di Desa Mranggen Kidul.

\section{METODE}

Metode yang digunakan adalah deskriptif dalam bentuk studi kasus. Pendekatan yang digunakan adalah asuhan keperawatan yang meliputi pengkajian, analisia data, merumuskan diagnosa keperawatan, perencanaan keperawatan, pelaksanaan keperawatan dan evaluasi.

Karakteristik untuk karya tulis ilmiah pada pasien yang mengalami malnutrisi dengan masalah keperawatan utama yaitu defisit nutrisi dengan kriteria subyek dari penelitian ini yaitu pasien dengan kategori bayi, pasien yang mengalami malnutrisi, pasien yang memiliki kesadaran composmentis, pasien atau keluarga pasien mampu berkomunikasi secara kooperatif, dan bersedia untuk dijadikan responden dan sudah menyetujui penelitian ini

Penelitian ini dilakukan kepada pasien yang mengalami malnutrisi dengan 
masalah keperawatan utama yaitu defisit nutrisi di Desa Mranggen Kidul pada 22 Februari 2021 sampai 28 Maret 2021.

Pengumpulan data yang digunakan yaitu menggunakan format pengkajian, proses perijinan melalui surat dan pengumpulan data menggunakan teknik wawancara, observasi dan pemeriksaan fisik. Alat yang digunakan dalam proses pengambilan data berupa format pengkajian asuhan keperawatan pada anak.

\section{HASIL}

Pengkajian dilakukan pada Senin, 22 Februari 2021 pukul 14.00 WIB di rumah Tn. S Maranggen Kidul dengan metode allowanamnesa. Pengambilan data yang dilakukan dengan teknik wawancara dan dokumentasi data di Puskesmas Bansari. Pengkajian ini dilakukan dalam waktu 2 hari yaitu tangal 22 Februari 2021 - 23 Februari 2021.

Pada data identitas pasien didapatkan bahwa pasien An. A berusia 10 bulan 26 hari, lahir di Temanggung, 27 Maret 2020 dari pasangan suami istri yaitu Tn. S dan Ny. E.

Keluhan utama pada pasien yaitu ibu pasien mengatakan nafsu makan pasien menurun sejak \pm 2 minggu. Saat dilakukan pengkajian di rumah pasien pada tanggal 22 Februari 2021 didapatkan hasil dengan S: $35,8^{\circ} \mathrm{C}$, RR: $30 \mathrm{x} / \mathrm{menit}, \mathrm{N} ; 118 \mathrm{x} / \mathrm{menit}$, BB: 5100 gram (tanpa lepas baju), PB; 64 $\mathrm{cm}$, LLA: $10 \mathrm{~cm}$, LK: $42 \mathrm{~cm}$, turgor kulit menurun dan kendur.

Pada riwayat masa lampau didapatkan data pada masa prenatal ibu pasien mengatakan pada saat hamil ibu pasien mengalami susah makan, sering mual, muntah dari awal kehamilan sampai sebelum persalinan. Pemeriksaan kehamilan dilakukan di bidan desa dan selama kehamilan ibu pasien mendapatkan obat penambah darah tetapi jarang diminum. Masa natal, ibu pasien melakukan persalinan secara spontan di Puskesmas
Bansari. Ibu pasien mengatakan saat pasien lahir waktunya maju 2 minggu dari waktu yang diperkirakan, yang seharusnya lahir pada bulan april menjadi bulan maret. Masa postnatal, ibu pasien mengatakan pasien lahir dalam keadaan sehat dengan berat badan lahir rendah 1900 gram, panjang badan lahir $47 \mathrm{~cm}$, dan tidak ada kelainan bawaan. Berdasarkan informasi dari ahli gizi puskesmas, ibu pasien sempat meninggalkan pasien saat pasien berusia 2 bulan dan selama ditinggal pasien diberi susu formula oleh keluarganya.

Pasien mempunyai riwayat kecelakaan yaitu pernah jatuh ke lantai saat digendong saudara Ny. E saat pasien berumur 7 bulan dan oleh keluarga dibawa kedukun untuk dipijatkan. Pasien tidak memiliki riwayat imunisasi.

Pada data riwayat sosial didapatkan data bahwa ibu pasien mengatakan pasien diasuh oleh ibunya. Saat pasien ditinggal oleh ibunya selama 2 minggu pasien sempat diasuh oleh ayah pasien, nenek pasien dan saudara ibu pasien. Ibu pasien mengatakan pasien rewel jika bertemu orang baru dan pasien tidak memiliki kebiasaan menghisap jari. Lingkungan rumah pasien tampak kotor dan kurang rapi, barang-barang tampak berserakan di lantai, terdapat 1 ventilasi yang terletak di dapur. Keadaan kesehatan saat ini pasien didiagnosis malnutrisi dan mendapatkan terapi obat dari puskesmas yaitu Kalsium (puyer) diminum 3 x 1 dengan dosis $150 \mathrm{mg}$, B kompleks (puyer) diminum $3 \times 1$ dengan dosis $60 \mathrm{mg}$, Amoxycillin (syrup) diminum $3 \times 1 / 2 \mathrm{sdm}$ dengan dosis $250 \mathrm{mg}$, Paracetamol (syrup) diminum $3 \times 1 / 2 \mathrm{sdm}$ dengan dosis $120 \mathrm{mg}$.

Pada pengkajian pola fungsional menurut Gordon, didapatkan data pola persepsi dan manajemen kesehatan ibu pasien mengatakan sejak lahir pasien jarang sakit, setelah lahir sampai sekarang tidak pernah mengikuti imunisasi dikarenakan ayah pasien meragukan apakah imunisasi itu halal atau haram. Pada pola nutrisi dan metabolik didapatkan data bahwa ibu pasien 
mengatakan pasien diberi ASI sampai pasien berumur 8 bulan karena pasien sudah tidak mau menyusu dan air ASI yang keluar hanya sedikit. Ibu pasien mengatakan sebelum sakit pasien diberi makan sun 3 kali sehari, pisang satu buah sehari dan minum susu formula $\pm 200 \mathrm{cc}$ dan air putih \pm 200 cc. Selama sakit ibu pasien mengatakan pasien makan sehari tiga kali, makan pagi hanya habis 2-3 sdm, makan siang $2 \mathrm{sdm}$, makan sore $2 \mathrm{sdm}$, dan waktu selingan pasien diberi 2 keping roti. Sehari pasien minum $\pm 180 \mathrm{cc}$ dan air putih \pm 150 cc. Pada pengkajian ABCD didapatkan data meliputi, A (antropometri) yaitu PB: $64 \mathrm{~cm}$, BB: 5100 gram (tanpa lepas baju), LLA: 10 cm, LK: $42 \mathrm{~cm}$, LP: $38,5 \mathrm{~cm}$, BB ideal: 9,5 kg. B (biochemical) tidak terkaji. C (Clinical Assesment) yaitu rambut pasien berwarna hitam kecoklatan dan kering, turgor kulit menurun dan kendur, CRT kembali $<3$ detik, mukosa bibir sedikit kering. D (Diit) yaitu ibu pasien mengatakan pasien makan nasi lemas, sayur lauk pauk, selingan diberi roti, dan susu formula).

Pemeriksaan fisik didapatkan data bahwa pasien tapak lemas dan kurus, hasil GCS : 15 , tanda-tanda vital $\left(\mathrm{S}: 35,8^{\circ} \mathrm{C}, \mathrm{N}\right.$ : $118 \mathrm{x} / \mathrm{menit}$, RR: $30 \mathrm{x} / \mathrm{menit}$ ), antropometri ( PB: $64 \mathrm{~cm}, \mathrm{BB}: 5100$ gram (tanpa lepas baju), LLA: $10 \mathrm{~cm}, \mathrm{LK}: 42 \mathrm{~cm}, \mathrm{LD}: 39 \mathrm{~cm}$ ), pada pengkajian bagian kepala didapatkan bahwa rambut pasien berwarna hitam kecoklatan dan sedikit kasar, pada mulut pasien yaitu mukosa bibir sedikit kering dan air liur yang terus menetes, pada dada tampak jelas tulang rusak pasien, pada abdomen perut pasien terlihat cekung, bising usus $10 \mathrm{x} /$ menit, pada kulit didapatkan bahwa turgor kulit menurun dan kedur, CRT < 3 detik dan tidak ada pembengkakan pada ekstremitas.

Pada pemeriksaan perkembangan yang dilakukan pada 22 Februari 2021 dengan 10 kuesioner yang didapatkan hasil bahwa pasien mengalami perkembangan tidak sesuai dengan usia bayi umur 10 bulan
26 hari dengan jumlah skor "YA" 5, yang artinya terjadi penyimpangan.

Pada pemeriksaan menentukan status gizi didapatkan data hasil Z-Score pada $\mathrm{BB} / \mathrm{U}$ yaitu $-4,1 \mathrm{SD}$ (gizi buruk), $\mathrm{PB} / \mathrm{U}$ yaitu -4,04 SD (sangat pendek), BB/PB yaitu -3,8 SD (sangat kurus), dan IMT/U yaitu -3,26 SD (sangat kurus).

Hasil pengkajian yang sudah dilakukan dan data yang sudah didapatkan kemudian dilakukan analisa data. Pada analisa data ini di kelompokkan menjadi data subjektif dan data objektif. Data subjektif yang didapatkan yaitu ibu pasien mengatakan nafsu makan pasien menurun sejak \pm 2 minggu, ibu pasien mengatakan pasien diberi ASI sampai pasien berumur 8 bulan karena pasien sudah tidak mau menyusu dan air ASI yang keluar hanya sedikit. Data objektif yang didapatkan yaitu pasien tampak lemas dan rewel, BB; 5100 gram, tanda-tanda vital $\left(\mathrm{S}: 35,8^{\circ} \mathrm{C}, \mathrm{N}: 118\right.$ $\mathrm{x} / \mathrm{menit}, \mathrm{RR}$ : $30 \mathrm{x} / \mathrm{menit}$ ), status gizi yaitu BB/U : $-4,1 \mathrm{SD}$ (gizi buruk), PB/U : $-4,04$ $\mathrm{SD}$ (sangat pendek), BB/PB : $-3,8 \mathrm{SD}$ (sangat kurus), dan IMT/U : -3,26 (sangat kurus). Dari analisa data tersebut dkemudian ditegakkan diagnosa utama keperawatan yaitu defisit nutrisi berhubungan dengan faktor psikologis (keengganan untuk makan).

Intervensi disusun berdasarkan prioritas masalah yang dialami oleh pasien pada Selasa, 23 Februari 2021. Prioritas penanganan pada pasien malnutrisi dengan masalah keperawatan defisit nutrisi dilakukan untuk akumulasi bobot tubuh supaya sesuai dengan usia dan jenis kelamin pasien. Tujuan dari intervensi yang telah disusun yaitu setelah dilakuan tindakan keperawatan dalam dua tahap yaitu selama $3 \times 24$ jam dan $2 \times 24$ jam masalah defisit nutrisi dapat teratasi dengan kriteria hasil berpedoman dari berat badan (L.03018) yaitu berat badan dari skala 1 (memburuk) menjadi skala 5 (membaik) dan indeks massa tubuh dari skala 1 (memburuk) menjadi skala 5 (membaik). Intervensi yang 
disusun menggunakan intervensi utama dan pendukung yaitu manajemen nutrisi (I.03119), promosi berat badan (I.03136), dan konseling nutrisi (I.03094).

Intervensi yang pertama sesuai dengan intervensi manajemen nutrisi (I.03119) yaitu identifikasi status nutrisi. Intervensi kedua yaitu berikan makanan tinggi kalori dan tinggi protein. Intervensi ketiga yaitu berikan suplemen makanan. Intervensi keempat yaitu ajarkan diet yang diprogramkan. Intervensi kelima yaitu kolaborasikan dengan ahli gizi untuk menentukan jumlah kalori dan jenis nutrien yang dibutuhkan.

Intervensi yang keenam sesuai dengan intervensi promosi berat badan (I.03136) yaitu identifikasi kemungkinan penyebab berat badan kurang. Intervensi ketujuh yaitu monitor berat badan. Intervensi kedelapan yaitu berikan perawatan mulut sebelum pemberian makanan. Intervensi kesembilan yaitu sediakan makanan yang tepat sesuai kondisi pasien. Intervensi kesepuluh yaitu jelaskan jenis makanan yang bergizi tinggi, namun tetap terjangkau. Intervensi yang terakhir sesuai dengan intervensi konseling nutrisi (I.03094) yaitu identifikasi kebiasaan makan dan perilaku makan yang akan diubah.

\begin{tabular}{ll}
\multicolumn{2}{c}{ Implemetasi yang dilakukan } \\
berdasarkan intervensi utama dan \\
pendukung yang telah disusun.
\end{tabular}
Implementasi dilakukan dalam waktu 3 x 24 jam tetapi setelah dilakukan evaluasi belum ada perubahan terhadap berat badan pasien, oleh karena itu penulis menambahkan waktu pengelolaan 2 x 24 jam. Implementasi pertama kali dilakukan pada Rabu, 24 Februari 2021 dan selesai pada Selasa, 23 Maret 2021.

Implementasi pertama yang dilakukan yaitu memonitor berat badan menggunakan timbangan bayi dengan hasil BB: $5,3 \mathrm{~kg}$ (tanpa lepas baju).

Kedua, mengidentifikasi status nutrisi dengan data yang diperlukan yaitu
BB: $5,3 \mathrm{~kg}$ (tanpa lepas baju), PB: $64 \mathrm{~cm}$, umur pasien 10 bulan 28 hari dengan hasil hitungan $\mathrm{BB} / \mathrm{U}$ : -3,9 SD (gizi buruk), $\mathrm{PB} / \mathrm{U}$ : $-4,04$ SD (sangat pendek), BB/PB: -3,4 SD (sangat kurus), IMT/U: -2,88 SD (kurus).

Ketiga, mengidentifikasi kebiasaan makan dan perilaku makan yang akan diubah yaitu terlalu lama menahan makanan dimulut setelah dikunyah, yang disebabkan karena tekstur makanan yang diberikan oleh ibu pasien bertekstur kasar dan kurang tepat untuk diberikan kepada pasien.

Keempat, mengidentifikasi kemungkinan penyebab berat badan berkurang yaitu karena pola asuh yang tidak tepat sehingga berat badan pasien berkurang sampai pasien mengalami malnutrisi.

Kelima, menyediakan makanan yang tepat sesuai kondisi pasien yaitu menyediakan nasi dengan tekstrur lemas dikarenakan pasien tidak mau memakan bubur. Saat diberi makanan bubur pasien akan langsung memuntahkannya.

Keenam, memberikan perawatan mulut sebelum pemberian makanan dengan cara membersihkan mulut pasien menggunakan tanggan dengan cara meggosok bagian dalam mulut pasien dan juga gigi psaien.

Ketujuh, memberikan makanan tinggi kalori dan tinggi protein yaitu nasi lemas, telur goreng, ikan dan pisang.

Kedelapan, memberikan suplemen makanan seperti modisco dan bubur tempe.

Kesembilan, menjelaskan jenis makanan yang bergizi tinggi namun tetap terjangkau seperti telur, tempe, ubi jalar, jeruk dan ikan.

Kesepuluh, mengajarkan diet yang diprogramkan yaitu makan makanan yang megandung lemak, protein, zat besi dan kalsium untuk memenuhi kebutuhan nutrisi pasien yang kurang.

Kesebelas, mengkolaborasikan dengan ahli gizi untuk menentukan jumlah kalori dan jenis nutrien yang dibutuhkan. 
Pihak gizi dari Puskesmas Bansari menganjurkan pasien diberi makanan yang bernutrisi dengan porsi sedikit tetapi sering.

Evaluasi dilakukan setelah selesai melakukan tindakan keperawatan. Evaluasi pertama pada Rabu, 24 Februari 2021 pukul 15.00 WIB dengan S (subjektif), ibu pasien mengatakan pasien sudah mulai diberi makan nasi lebih lunak yaitu nasi dengan teksytur lebih lemas. O (objektif), pasien tampak lemas dan rewel, umur, 10 bulan 28 hari, BB: 5,3 kg (tanpa lepas baju), PB: 64 $\mathrm{cm}$, status nutrisi (BB/U: $-3,95$ SD (gizi buruk), PB/U: -4,04 SD (sangat pendek), BB/PB: -3,5 SD (sangat kurus), IMT/U: 2,95 SD (kurus). A (assesment), defisit nutrisi belum teratasi. P (plan), intervensi perlu dilanjutkan diantaranya monitor berat badan, identifikasi status nutrisi, sediakan makanan yang tepat sesuai dengan kondisi pasien, berikan perawatan mulut sebelum pemberian makanan, berikan makanan tinggi kalori dan tinggi protein, dan berikan suplemen makanan.

Evaluasi hari kedua pada Kamis, 25 Februari 2021pukul 15.00 WIB dengan S(subjektif), ibu pasien mengatakan pasien hanya minum minuman modisco $2 \mathrm{sdm}$ saja, ibu pasien mengatakan pasien hanya menghabiskan minuman modisco $2 \mathrm{sdm}$ dan ibu pasien mengatakan setiap pasien makan hanya menghabisan 2-3 sdm. O (objektif), yang didapatkan yaitu pasien tampak lemas dan rewel, umur 10 bulan 29 hari, BB: $5 \mathrm{~kg}$ (lepas baju), PB: $64 \mathrm{~cm}$, BB/U: -4,2 SD (gizi buruk), PB/U: -4,04 SD (sangat pendek), BB/PB: -4 SD (sangat kurus), IMT/U: $-4,5$ SD (sangat kurus). A (assesment), defisit nutrisi belum teratasi. $\mathrm{P}$ (plan), intervensi perlu dilanjutkan diantaranya monitor berat badan, identifikasi status nutrisi, sediakan makanan yang tepat sesuai kondisi pasien, memberikan perawatan mulut sebelum pemberian makanan, dan berikan makanan tinggi kalori dan tinggi protein.

Evaluasi hari ketiga pada Jumat, 26 Februari 2021 pukul 15.00 WIB dengan S (subjektif), ibu pasien mengatakan setiap pasien makan hanya habis 2-3 sdm dan ibu pasien mengatakan setelah diberi minum modisco pasien mengalami sedikit diare. $\mathrm{O}$ (objektif), yang didapatkan yaitu umur 10 bulan 30 hari, BB: $5 \mathrm{~kg}$ (lepas baju), PB: 64 cm, BB/U: -4,2 SD (gizi buruk), PB/U: 4,04 SD (sangat pendek), BB/PB: -4 SD (sangat kurus), IMT/U: -4,5 SD (sangat kurus). A (assesment), defisit nutrisi belum teratasi. P (plan), intervensi perlu dilanjutkan diantaranya monitor berat badan, identifikasi status nutrisi, berikan makanan tinggi kalori dan tinggi protein.

Evaluasi hari keempat pada Rabu, 17 Maret 2021 pukul 15.00 WIB dengan S (subjektif), ibu pasien mengatakan nafsu makan pasien mulai bertambah yang biasanya habis 2-3 sdm tiap makan dan sekarang menjadi 4-5 sdm tiap makan. O (objektif), yaitu umur 11 bulan 21 hari BB: $5 \mathrm{~kg}$ (lepas baju), PB: $64,5 \mathrm{~cm}, \mathrm{BB} / \mathrm{U}:-4,4$ $\mathrm{SD}$ (gizi buruk), $\mathrm{PB} / \mathrm{U}$ : $-4,3 \mathrm{SD}$ (sangat pendek), BB/PB: -4,3 SD (sangat kurus), IMT/U: $-3,75$ SD (sangat kurus). A (assesment), defisit nutrisi belum teratasi. P (plan), intervensi perlu dilanjutkan diantaranya monitor berat badan, identifikasi status nutrisi.

Evaluasi hari kelima pada Selasa, 23 Maret 2021 pukul 15.00 WIB dengan S (subjektif), ibu pasien mengatakan pasien sudah tidak mengalami diare. O (objektif), yaitu umur 11 bulan 27 hari, BB: $5,1 \mathrm{~kg}$ (lepas baju), PB: $65 \mathrm{~cm}, \mathrm{BB} / \mathrm{U}:-4,3 \mathrm{SD}$ (gizi buruk), $\mathrm{PB} / \mathrm{U}$ : $-4,1$ SD (sangat pendek), BB/PB: -3,6 SD (sangat kurus), IMT/U: $-3,7$ SD (sangat kurus). A (assesment), defisit nutrisi belum teratasi. $\mathrm{P}$ (plan), intervensi perlu dilanjutkan diantaranya monitor berat badan, identifikasi status nutrisi.

\section{PEMBAHASAN}

Pengkajian dilakukan oleh penulis di rumah Tn. S di Desa Mranggen Kidul. Pengkajian dilakukan dengan metode allowanamnesa, dengan hasil ibu pasien 
mengatakan nafsu makan pasien berkurang \pm 2 minggu. Nafsu makan berkurang merupakan keengganan seseorang berkeinginan untuk makan. Nafsu makan yang berkurang membuat seseorang lebih jarang merasa lapar, makan lebih sedikir dari biasanya, atau merasa kenyang meskipun baru makan sedikit (Adrian, 2019c).

Pada pengkajian ABCD didapatkan data A (antropometri), yaitu PB: $64 \mathrm{~cm}$, sedangkan panjang badan bayi normal lakilaki umur 10 bulan yaitu sekitar $73-78 \mathrm{~cm}$ (Nareza, 2020). BB: 5100 gram (tanpa lepas baju), sedangkan berat badan bayi normal laki-laki umur 10 bulan yaitu sekitar $9-11 \mathrm{~kg}$ (Nareza, 2020). LLA: $10 \mathrm{~cm}$, sedangkan lingkar lengan atas normal bayi umur 10 bulan yaitu 14,6 cm WHO (dalam Adzani, 2020). LK: $42 \mathrm{~cm}$, sedangkan ukurang lingkar kepala bayi laki-laki umur 10 bulan yaitu 42,9-47,9 cm (Setiaputri, 2021).

B (biochemical), tidak terkaji dikarenakan di puskesmas tidak ada data laboratorium. C (clinical assesment), yaitu turgor kulit menurun dan kendur. Menurut (Kusumawardani, 2019), turgor kulit menurun merupakan salah satu tanda bahwa seseorang mengalami kekurangan cairan yang cukup berat. Selain mengalami kekurangan cairan pasien juga mengalami kekurangan asupan nutrisi yang menyebabkan rambut pasiem menjadi kering dan mudah rontok. Rambut pasien berwarna hitam kecoklatan dan kering, Menurut (Rahmawati, 2011), biasanya rambut kering menunjukkan pola makan kurang omega-3, asam lemak esensial yang terdapat dalam ikan salmon dan minyak ikan, kacang walnut, dan biji rami. CRT kembali < 3 detik. Mukosa bibir sedikit kering. Menurut (Pane, 2020), penyebab bibir kering yaitu dehidrasi, penyakitpenyakit tertentu, kebiasaan bernafas melalui mulut dan lain-lain.

D (diit), yaitu ibu pasien mengatakan pasien makan nasi lemas, sayur lauk pauk, selingan diberi roti dan susu formula. Pasien mendapatkan program diit ini setelah periksa ke puskesmas.

Pada pemeriksaan dada tampak jelas tulang rusuk pasien. Tanda tulang rusuk terlihat dengan jelas ini dikarenakan hilangnya massa lemak tubuh dan jaringan otot (Saraswati, 2020). Pada pemeriksaan abdomen perut pasien terlihat cekung. Pada penderita malnutrisi memiliki perut yang cekung dikarenakan tubuh kekurangan berbagai macam gizi (Akg, 2019).

Setelah penulis melakukan pengkajian terhadap pasien, selanjutnya penulis merumuskan diagnosa utama yang muncul pada pasien yaitu defisit nutrisi berhubungan dengan faktor psikologis (keengganan untuk makan). Defisit nutrisi adalah kurangnya asupan nutrisi untuk tubuh. Defisit nutrisi disebabkan oleh ketidakmampuan menelan makanan, ketidakmampuan mencerna makanan, ketidakmampuan mengabsorbsi nutrien, peningkatan kebutuhan metabolisme, faktor ekonomi, faktor psikologis (Tim Pokja SDKI DPP PPNI, 2016). Keengganan untuk makan merupakan sebuah kondisi psikologis yang mengarah ke gangguan dalam makan atau istilah lainnya anoreksia yaitu hilangnya selera makan (Admin, 2019).

Pada kasus ini pasien berumur 10 bulan sehingga dinamakan anoreksia infartil. Anoreksia infartil yaitu terjadinya gangguan pola makan yang muncul antara usia 6 bulan sampai dengan 3 tahun. Penyebab anoreksia pada bayi atau anoreksia infartil bisa disebabkan oleh terlalu banyaknya distraksi, abnormalitas mulut, obat-obatan persalinan tertentu, frenulum kencang (jaringan keputihan dibawah lidah yang kencang), asupan nutrisi tidak tepat, asupan makanan terganggu dan cedera fisik (Sera, 2020).

Proses anoreksia infartil sehingga menjadi defisit nutrisi yaitu pada anak usia 3 bulan sampai 3 tahun ini, anak mulai mengalami transmisi makan sendiri menggunakan sendok namun banyak 
ditemukan kasus bahwa anak lebih tertarik dengan rangsangan luar sehingga menyebabkan anak tidak tertarik untuk makan atau melanjutkan makan yang sempat tertunda. Sehingga menyebabkan asupan nutrisi yang diterima anak sedikit dan konsisi ini bisa menyebabkan asupan nutrisi tidak tercukupi untuk kebutuhan metabolisme pada tubuh (Kadarhadi, 2012). Dalam diagnosa keperawatan disebut dengan defisit nutrisi.

Defisit nutrisi menyebabkan penurunan berat badan yang diakibatkan karena adanya gangguan dalam penyerapan makanan. Gangguan penyerapan ini akan menyebabkan timbulnya keluhan dan gejala yang beragam, mulai dari diare yang terus menerus hingga malnutrisi (Pane, 2020). Gangguan penyerapan ini biasanya disebut sebagai malabsorpsi makanan. Malabsorpsi atau sindrom malabsorpsi adalah kumpulan gejala yang disebabkan oleh gangguan penyerapan salah satu atau beberapa zat nutrisi di usus halus (Pane, 2020).

Gizi (nutrition) adalah suatu proses organisme menggunakan makanan yang dikonsumsi secara normal melalui proses digesti, absorpsi, transportasi, penyimpanan, metabolisme dan pengeluaran zat-zat yang tidak digunakan lagi oleh tubuh, proses untuk mempertahankan kehidupan, pertumbuhan, perkembangan dan fungsi normal dari organ-organ, serta menghasilkan energi (Alristina et al., 2021). Zat gizi yang berperan dalam mengatur proses tubuh yaitu protein, mineral, vitamin dan air. Jika tubuh kekurangan gizi dalam jangka panjang maka bisa menyebabkan terjadinya malnutrisi (Adrian, 2019a).

Malnutrisi adalah kondisi ketika seseorang mengalami kekurangan nutrisi atau nutrisinya dibawah rata-rata ( $\mathrm{K}$ et al., 2021). Menurut (Sutrio et al., 2021), anak dapat mengalami malnutrisi karena beberapa sebab, pertama karena praktik menyusui yang tidak memadai dan pola makan yang buruk ditambah praktik pengasuhan yang tidak optimal, kedua yaitu nutrisi dan perawatan yang tidak memadai bagi ibu dan perempuan hamil, dan ketiga yaitu tingginya angka penyakit menular utamanya akibat lingkungan tempat tinggal yang tidak bersih dan kurang memadainya akses ke layanan kesehatan.

Gejala dan tanda yang didapat pada pasien yaitu nafsu makan pasien menurun dan berat badan pasien kurang dari normal. Menurut penulis gejala dan tanda pada defisit nutrisi didapatkan dari data subjektif bahwa ibu pasien mengatakan nafsu makan pasien menurun sejak \pm 2 minggu dan data objektif dari berat badan pasien yang kurang dari normal yaitu 5100 gram dan hasil perhitungan status gizi yaitu $\mathrm{BB} / \mathrm{U}:-4,1 \mathrm{SD}$ (gizi buruk), $\mathrm{PB} / \mathrm{U}:-4,04 \mathrm{SD}$ (sangat pendek), BB/PB : -3,8 SD (sangat kurus), dan IMT/U : -3,26 (sangat kurus).

Penulis mengambil atau menegakkan diagnosa keperawatan defisit nutrisi berhubungan dengan faktor psikologis (keenganan untuk makan), dikarenakan dalam data tertulis bahwa ibu pasien mengatakan nafsu makan pasien menurun \pm 2 minggu, berat badan 5100 gram (kurang dari normal) dan status gizi yang kurang dari normal.

Pada tahap ini penulis akan membahas perencanaan tindakan keperawatan sesuai dengan masalah yang dialami pasien. Perencanaan merupakan petunjuk yang digunakan untuk menggambarkan rencana tindakan yang akan dilakukan terhadap pasien berdasarkan masalah yang dialami pasien. Perencanaan keperawatan adalah rencana tindakan keperawatan yang dilakukan oleh perawat kepada klien dengan tujuan untuk mencapai kesejahteraan kesehatan klien dan kemandirian klien menjaga kesehatannya (Safira, 2019). Penulis menegakkan intervensi berdasarkan SIKI yang ditegakkan pada Selasa, 23 februari 2021. Penulis akan membahas mengenai intervensi untuk mengatasi masalah keperawatan defisit nutrisi berhubungan 
dengan faktor psikologis (keengganan untuk makan).

Dalam kasus pasien An. F didapatkan tujuan dari intervensi yaitu setelah dilakukan tindakan keperawatan selama 3 x 24 jam masalah defisit nutrisi dapat teratasi dengan kriteria hasil berpedoman pada berat badan di SLKI yaitu berat badan dari skala 1 (memburuk) menjadi skala 5 (membaik) dan indeks massa tubuh dari skala 1 (memburuk) menjadi skala 5 (membaik) (Tim Pokja SIKI DPP PPNI, 2018).

Intervensi yang pertama yaitu identifikasi status nutrisi. Intervensi ini ditegakkan untuk mengetahui status nutrisi pasien apakah status nutrisi pasien kurang, normal atau berlebihan. Status gizi adalah cerminan ukuran terpenuhinya kebutuhan gizi yang didapatkan dari asupan dan penggunaan zat gizi oleh tubuh (Utama \& Herqutanto, 2014).

Intervensi yang kedua yaitu berikan makanan tinggi kalori dan tinggi protein. Intervensi ini ditegakkan untuk memenuhi kebutuhan kalori dan protein yang harus dipenuhi oleh pasien. Makanan tinggi kalori terdiri dari daging merah, kacang-kacangan, nasi, alpukat, dark chocolate, kurma, salmon, keju, pisang, paha ayam, minyak kelapa, minyak zaitun, margarin, susu, ubi jalar dan kentang (Damay, 2021). Makanan tinggi protein terdiri dari telur, kacang almond, dada ayam, gandum, keju cottage, yogurt, susu, daging sapi, ikan tuna dan udang (Swari, 2020).

Intervensi yang ketiga yaitu berikan suplemen makanan. Intervensi ini ditegakkan untuk menambah berat badan pasien dan untuk mencukupi asupan nutrisi. Suplemen makanan adalah produk yang dirancang untuk melengkapi gizi yang dibutuhkan tubuh, seperti vitamin, mineral, serat, asam amino dan asam lemak (Natasha, 2020).

Intervensi yang keempat yaitu ajarkan diet yang diprogramkan. Intervensi ini ditegakkan untuk mengajarkan dan mengatur pola makan dan jenis makanan apa yang harus pasien konsumsi dalam proses penambahan berat badan dan menormalkan status gizi pasien. Menurut Persatuan Ahli Gizi Indonesia (dalam Riadi, 2019), diet adalah pengaturan pola dan konsumsi makanan serta minuman yang dilarang, dibatasi jumlahnya, dimodifikasi, atau diperbolehkan dengan jumlah tertentu untuk tujuan terapi penyakit yang diderita, kesehatan, atau penurunan berat badan.

Intervensi yang kelima yaitu kolaborasikan dengan ahli gizi untuk menentukan jumlah kalori dan jenis nutrien yang dibutuhkan. Intervensi ini ditegakkan untuk mengetahui lebih jelas dalam memberikan tindakan kepada pasien. Jumlah kalori yang dibutuhkan pada usia bayi 10 bulan rata-rata 793 kalori (Kristyani, 2019).

Intervensi yang keenam yaitu identifikasi kemungkinan penyebab berat badan kurang. Intervensi ini ditegakkan untuk mengetahui penyebab berat badan pasien berkurang. Penyebab berat badan bayi menurun yaitu kurangnya asupan makanan, bayi sedang bergerak aktif dan adanya gangguan kesehatan (Babyologist, 2018).

Intervensi yang ketujuh yaitu monitor berat badan. Intervensi ini ditegakkan untuk mengetahui berat badan pasien apakah ada pertambahan atau tidak. Memonitor berat badan bertujuan untuk menunjukkan bahwa sudah terjadi keseimbangan zat gizi di dalam tubuh setelah melakukan pemantauan berat badan (Fazrul, 2020). Indikator yang digunakan yaitu tercapainya berat badan sesuai ratarata atau normal.

Intervensi yang kedelapan yaitu berikan perawatan mulut sebelum pemberian makanan. Intervensi ini ditegakkan untuk membunuh bakteri dalam mulut sehingga makanan yang masuk tidak tercampur atau terkontaminasi oleh bakteri. Oral hygiene adalah suatu perawatan mulut dengan atau tanpa menggunakan antiseptik 
untuk memenuhi salah satu kebutuhan personal hygiene klien (Riadi, 2012). Oral hygiene dapat menggunakan air bersih, hangat dan matang.

Intervensi yang kesembilan yaitu sediakan makanan yang tepat sesuai kondisi pasien. Intervensi ini ditegakkan untuk menghindari terjadinya masalah lain yang akan timbul jika penulis menyediakan makanan yang tidak sesuai dengan kondisi pasien.

Intervensi yang kesepuluh yaitu jelaskan jenis makanan yang bergizi tinggi, namun terjangkau. Intervensi ini ditegakkan untuk memberitahukan kepada ibu pasien jenis makanan bergizi apa saja yang mudah didapat dan terjangkau untuk pasien beli atau dapatkan. Jenis makanan yang bergizi tinggi dan tejangkau seperti sayur, buah, telur dan daging, biji-bijian dan kacangkacangan, ikan dan susu (Indra, 2021).

Intervensi yang kesebelas yaitu identifikasi kebiasaan makan dan perilaku makan yang akan diubah. Intervensi ini ditegakkan untuk merubah kebiasaan buruk pasien saat makan menjadi lebih baik. Kebiasaan makan yaitu tingkah laku manusia atau kelompok manusia dalam memenuhi kebutuhan akan makan yang meliputi sikap, kepercayaan dan pemilihan makanan (Kant et al., 2013).

Berdasarkan rencana tindakan keperawatan di atas penulis akan melakukan tindakan sesuai dengan yang sudah direncanakan. Implementasi keperawatan merupakan pelaksanaan atau perwujudan dari intervensi yang sudah ditetapkan dengan tujuan yang sama yaitu untuk memenuhi kebutuhan pasien dan meningkatkan status kesehatannya (Lingga, 2019). Penulis melakukan implementasi keperawatan dimulai tanggal 24 Februari 2021 dan selesai pada Selasa, 23 Maret 2021.

Implementasi yang pertama yaitu memonitor berat badan. Dalam melakukan pengukuran berat badan menggunakan alat pengukur berat badan bayi. Dari tindakan yang sudah dilakukan didapatkan data bahwa BB: 5,3 kg (tanpa lepas baju), dari $\mathrm{BB}$ tersebut hasilnya $\mathrm{BB}$ pasien kurang dari normal BB normal bayi usia 10 bulan. Menurut WHO (dalam Sari, 2020), berat badan bayi laki-laki umur 10 bulan yaitu 9$11 \mathrm{~kg}$.

Implementasi yang kedua yaitu mengidentifikasi status nutrisi dengan menggunakan perhitungan $\mathrm{z}$-score, data tambahan yang diperlukan PB: $64 \mathrm{~cm}$, umur pasien 10 bulan 28 hari, perhitungan status nutrisi yang didapatkan yaitu BB/U: -3,9 SD (gizi buruk), $\mathrm{PB} / \mathrm{U}$ : $-4,04 \mathrm{SD}$ (sangat pendek), BB/PB: -3,4 SD (sangat kurus), IMT/U: -2,88 SD (kurus). Dari data yang sudah didapat pasien mengalami gizi buruk atau malnutrisi. Gizi buruk atau malnutrisi dapat diartikan sebagai asupan gizi yang buruk (Aryanto \& Pujianta, 2013).

Implementasi yang ketiga yaitu mengidentifikasi kebiasaan makan dan perilaku makan yang akan diubah. Kebiasaan makan yaitu suatu istilah yang menggambarkan kebiasaan dan perilaku yang berhubungan dengan makanan dan makan, seperti tata krama makan, pola makanan yang dimakan, frekuensi dan porsi makanan, kepercayaan dan penerimaan terhadap makanan, distribusi makanan di antara anggota keluarga, dan cara pemilihan bahan makanan yang hendak dimakan (Hasanah et al., 2013).

Implementasi yang keempat yaitu mengidentifikasi kemungkinan penyebab berat badan berkurang. Berdasarkan penelitian yang dilakukan oleh (Masyudi et al., 2019), mengatakan bahwa kemungkinan lebih besar pola asuh yang tidak tepat dapat mempengaruhi status gizi bayi.

Implementai yang kelima yaitu menyediakan makanan yang tepat sesuai kondisi pasien. Makanan yang disediakan yaitu nasi dengan tekstur lemas agar pasien lebih mudah memakannya. Tujuan diberikannya makanan yang disesuaikan dengan kondisi pasien yaitu untuk memenuhi kebutuhan nutrisi pasien selama 
masa perawatan di rumah sakit (Mustinda, 2016).

Implementasi yang keenam yaitu memberikan perawatan mulut sebelum pemberian makanan dengan cara membersihkan bagian dalam mulut pasien menggunakan tangan. Perawat melakukan perawatan mulut (oral hygiene) untuk menghilangkan bakteri pada mulut pasien. Manfaat membersihkan mulut bayi yaitu untuk menghilangkan racun, langkah awal kesehatan gigi dan agar indra perasa dapat bekerja dengan baik (Tanhati, 2018).

Implementasi yang ketujuh yaitu memberikan makanan tinggi kalori dan tinggi protein seperti telur, ikan dan pisang. Pada tahap awal ini diberikan makanan tinggi kalori setelah terpenuhi baru diberikan makanan tinggi protein dengan kadar lebih rendah agar saluran cerna tidak kaget jika langsung diberi dengan kadar tinggi (Noya, 2018).

Kandungan yang terdapat dalam telur yaitu ada protein, kalori, vitamin A, vitamin B2, vitamin B5, Vitamin B12, dan lemak (Indra, 2021). Manfaat telur yaitu seperti kaya nutrisi, sumber kolestrol baik, menurunan trigliserida, menyehatkan jantung, mengenyangkan lebih lama, mendukung kesehatan mata, dan mempertajam otak (Yuniar, 2019). Kandungan dalam ikan yaitu protein, karbohidrat, vitamin, mineral, dan asam lemak omega 3. Adapun manfaat dari ikan yaitu kaya akan kandungan nutrisi, menurunkan risiko serangan jantung dan stroke, meningkatkan kinerja otak, mencegah depresi, sumber vitamin D yang baik, menurunkan risiko penyakit autoimun, mencegah asma pada anak-anak, menjaga kesehatan mata, meningkatkan kualitas tidur, menurunkan risiko kanker, dan menstabilkan tekanan darah (Kosasih, 2021). Kandungan dalam pisang yaitu kalori, air, protein, karbohidrat, gula, serat, lemak, dan kalium (Azizah, 2021). Manfaat buah pisang yaitu membantu atasi hipertensi, sumber karbohidrat dan vitamin
A, Pisang perlancar metabolisme, meningkatkan kekebalan tubuh, melancarkan aliran oksigen ke otak, mengatai anemia, tulan dan untuk merawat kulit (Kemenkes RI, 2018).

Implementasi yang kedelapan yaitu memberikan suplemen makanan. Pada pemberian suplemen makanan ini yang diberikan yaitu modisco sebagai makanan tambahan dan bubur tempe. Modisco adalah salah satu formula yang dapat membantu untuk menambah berat badan bayi pada malnutrisi (Arolyumna et al., 2016). Modisco yang diberikan pada pasien yaitu modisco II dikarenakan pasien tidak mengalami edema. Pada pembuatan ini memerlukan 3 bahan yaitu susu skim 10 gram, gula pasir 5 gram dan margarin 5 gram. Cara pembuatan minuman modisco II ini yang pertama yaitu larutkan margarin dalam air, kemudian larutkan gula pasir dan susu dalam air, kemudian campur kedua larutan tersebut setelah itu minum minuman modisco hangat-hangat. Nilai gizi yang terdapat dalam modisco II yaitu energi 100 kal, protein 3,6 gram dan lemak 5 gram (Sandi, 2013). Pemberian bubur tempe ini dikarenakan setelah pasien diberi minuman modisco pasien mengalami diare, oleh karena itu oleh perawat diberikan makanan bubur tempe untuk mengatasi diare. Bahanbahan pembuatan bubur tempe yaitu beras $1 / 2$ gelas, tempe 50 gram (2 potong), wortel 50 gram (1/2 gelas) dicincang kecil, garam, dan gula. Cara pembuatannya yaitu pertama masukkan beras dan air sampai melunak, setelah agak melunak masukkan tempe yang sudah diblender dan wortel. Kemudian beri sedikit garam dan gula. Kemudian aduk sampai matang (Wiliam, 2021). Beradasarkan penelitian (Rachmawati et al., 2020), kandungan zat gizi yang terdapat pada bubur tempe per porsi yaitu energy $125,02 \mathrm{Kkal}$, protein 3 gram, lemak 12 gram, karbohidrat 9,83 gram, kadar air 0,0316 gram dan pengabuan 1,92 gram.

Implementasi yang kesembilan yaitu menjelaskan jenis makanan yang berigizi tinggi, namun terjangkau. Biasanya pertama 
kamli pola makan yang dianjurkan oleh ahli gizi yaitu makanan tinggi protein yang digunaan sebagai pondasi untuk membentuk otot, kulit, hormon dan semua sel dan jaringan tubuh (Adrian, 2020).

Implementasi yang kesepuluh yaitu mengajarkan diet yang diprogramkan. Diet makanan yang diprogramkan yaitu makan makanan yang mengandung lemak, protein, zat besi dan kalsium. Lemak yang dibutuhkan pada bayi umur 6-12 bulan sebagai MPASI $\pm 32-58,9 \%$ dari total energi, makanan yang disarankan sebagai sumber lemak untuk MPASI seperti alpukat, keju, yogurt, hummus dan olive oil (Puteri, 2020). Zat besi yang dibutuhkan pada bayi umur 7-11 bulan memerlukan 7-11 mg per hari, sumber makanan dari zat besi seperti daging sapi, kambing, ayam atau ikan, hati ayam atau hati sapi, telur, sayuran (bayam, keciwis, brokoli), kacang-kacangan (kacang merah, kedelai), tahu dan tempe, sereal yang difortikasi zat besi dan oatmeal (Adrian, 2019b). Kalsium yang dibutuhkan yaitu untuk bayi usia 6-12 bulan yaitu $270 \mathrm{mg}$ kalsium, bahan MPASI yang baik untuk tulang bayi yaitu yoghurt, ikan sarden, bayam, brokoli, ikan salmon, tahu dan plum (KumparanMOM, 2020).

Implementasi yang kesebelas yaitu mengkolaborasikan dengan ahli gizi untuk menentukan jumlah kalori dan jenis nutrien yang dibutuhkan.

Evaluasi disusun menggunakan SOAP diamana $\mathrm{S}$ (ungkapan perasaan atau keluhan yang dikeluhkan secara subjektif oleh keluarga setelah diberikan implementasi keperawatan), O (keadaan objektif yang dapat diidentifikasi oleh perawat menggunakan pengamatan yang objektif), A (analisis perawat setelah mengetahui respon subjektif dan objektif), $\mathrm{P}$ (perencanaan selanjutnya setelah perawat melakukan analisi) (Harahap, 2019).

Evaluasi pada tahap kedua ini pada hari terakhir atau hari kelima pada Selasa, 23 Maret 2021 pukul 15.00 WIB dengan S (subjektif), ibu pasien mengatakan pasien sudah tidak mengalami diare. O (objektif), yaitu umur 11 bulan 27 hari, BB: $5,1 \mathrm{~kg}$ (lepas baju), PB: $65 \mathrm{~cm}, \mathrm{BB} / \mathrm{U}:-4,3 \mathrm{SD}$ (gizi buruk), $\mathrm{PB} / \mathrm{U}$ : $-4,1 \mathrm{SD}$ (sangat pendek), BB/PB: -3,6 SD (sangat kurus), IMT/U: $-3,7$ SD (sangat kurus). A (assesment), defisit nutrisi belum teratasi. $\mathrm{P}$ (plan), intervensi perlu dilanjutkan diantaranya monitor berat badan, identifikasi status nutrisi.

Selama melakukan pengelolaan keperawatan dalam 2 tahap yaitu 3 x 24 jam dan 2 x 24 jam, penulis menyimpulkan bahwa dalam keberhasilan pengelolaan terdapat faktor pendukung dan faktor penghambat. Faktor pendukung dalam pemberian asuhan keperawatan pada pasien yaitu keterlibatan keluarga pasien dalam menjalankan rencana tindakan keperawatan pada pasien. Faktor penghambat dalam proses pemberian asuhan keperawatan pada pasien yaitu saat dilakukan tindakan pasien rewel dan terkadang menangis. Tindakan yang dilakukan untuk mengatasi faktor penghambat tersebut yaitu pasien digendong oleh ibu pasien.

\section{KESIMPULAN}

Masalah keperawatan defisit nutrisi berhubungan dengan faktor psikologis (keengganan untuk makan) belum teratasi setelah dilaukan tindakan keperawatan $5 \mathrm{x}$ 24 jam. Tetapi sudah ada perkembangan berat badan pasien sebesar $0,1 \mathrm{~kg}$ selama 25 hari.

Diharapkan bagi keluarga dan masyarakat agar lebih memperhatikan lagi status gizi anak dengan memperhatikan keseimbangan asupan zat gizi pada anak dan memperbaiki kualitas makan anak karena masa anak-anak merupakan masa pertumbuhan yang rentan mengalami masalah dan juga agar lebihmemperhatikan status gizi ibu hamil agar janin yang dikandung nutrisinya tetapterpenuhi 


\section{DAFTAR PUSTAKA}

Admin. (2019). Mengenal Istilah Gangguan Makan Dalam Psikologi. https://www.psikoma.com/mengenalistiah-gangguan-makan-dalampsikologi/

Adrian, K. (2019a). 14 Tanda Tubuh Kamu Kekurangan Gizi. Artikel Alodokter. https://www.alodokter.com/11-tandatubuh-kamu-kekurangan-gizi

Adrian, K. (2019b). Kebutuhan Zat Besi untuk Bayi.

https://www.alodokter.com/kebutuhan -zat-besi-untuk-bayi

Adrian, K. (2019c). Penyebab Berbahaya di Balik Nafsu Makan Berkurang. https://www.alodokter.com/penyebabberbahaya-di-balik-nafsu-makanberkurang

Adrian, K. (2020). Pola Makan yang Dianjurkan Ahli Gizi. https://www.alodokter.com/perhatikan -anjuran-makanan-dari-ahli-giziberikut

Adzani, F. (2020). Serba-serbi LILA (Lingkar Lengan Atas) dan Cara Mengukurnya pada Bayi. https://today.line.me/id/v2/article/nRL jjx

Akg. (2019). Kenali Perbedaan Marasmus dan Kwashiorkor.

https://akg.fkm.ui.ac.id/kenaliperbedaan-marasmus-dankwashiorkor/

Alristina, A. D., Ethasari, R. K., Laili, R. D., \& Hayudanti, D. (2021). ILMU GIZI DASAR. CV. Sarnu Untung. https://books.google.co.id/books?id=w RovEAAAQBAJ\&printsec $=$ frontcover $\& d q=z a t+$ gizi + adalah $\& h l=e n \& s a=X \&$ redir_esc $=\mathrm{y} \# \mathrm{v}=$ onepage $\& \mathrm{q}=$ zat gizi adalah $\& \mathrm{f}=$ false

Arolyumna, Prihatin, \& Subandriani. (2016). Pengaruh Pemberian Es Krim Modisco Terhadap Kenaikan Berat Badan Pada Balita Gizi Kurang. 4(1), 49-54.

file:///C:/Users/User/Downloads/4288-
12244-1-SM.pdf

Aryanto, D., \& Pujianta, A. (2013).

Aplikasi Sistem Pakar Penentuan

Asupan Makanan Bagi Penderita

Penyakit Gizi Buruk dengan Inferensi

Fuzzy. Jurnal Sarjana Teknik

Informatika, 1(2), 432-439.

https://core.ac.uk/download/pdf/29696 9526.pdf

Azizah, K. (2021). 13 Kandungan Buah

Pisang, Tingkatkan Vitalitas dan

Ereksi Kuat Salah Satunya.

https://www.merdeka.com/trending/13

-kandungan-buah-pisang-tingkatkan-

vitalitas-dan-ereksi-kuat-salah-

satunya-kln.html?page $=2$

Babyologist. (2018). Berikut Penybebab

Berat Badan Bayi Menurun.

https://kumparan.com/babyologist/beri

kut-penyebab-berat-badan-bayi-

menurun/full

Damay. (2021). Deretan Makanan Tinggi

Kalori yang Wajib Anda Ketahui.

https://www.klikdokter.com/info-

sehat/read/2697323/ deretan-makanantinggi-kalori-yang-wajib-anda-ketahui

Fazrul, I. (2020). 4 Cara Menerapkan

Pedoman Gizi Seimbang Dalam

Kehidupan Sehari-hari.

https://www.99.co/blog/indonesia/ped oman-gizi-seimbang/

Hanifah, R. N., Djais, J. T. B., \& Fatimah, S. N. (2019). Prevalensi Underweight, Stunting, dan Wasting pada Anak Usia 12-18 Bulan di Kecamatan Jatinangor. JSK, 5(3), 1-5.

https://doi.org/file:///C:/Users/User/Do wnloads/28768-92682-1-

PB\%20(1).pdf. Diunduh pada tanggal

7 Maret 2021 pukul 11.14 WIB

Harahap, E. E. (2019). Melaksanakan

Evaluasi Asuhan Keperawatan Untuk

Melengkapi Proses Keperawatan.

https://osf.io/mr4ws

Hasanah, D. N., Febrianti, \& Minsarnawati.

(2013). Kebiasaan Makan Menjadi

Salah Satu Penyebab Kekurangan

Energi Kronis (Kek) Pada Ibu Hamil

Di Poli Kebidanan Rsi\&A Lestari

Cirendeu Tangerang Selatan. Jurnal 
Kesehatan Reproduksi, 3(3), 91-104. https://media.neliti.com/media/publica tions/106703-ID-kebiasaan-makanmenjadi-salah-satu-penye.pdf

Indra, R. (2021). Kandungan Gizi Telur Bagi Tubuh yang Jarang Diketahui. https://www.lemonilo.com/blog/kandu ngan-gizi-telur-bagi-tubuh-yangjarang-diketahui

K, F. A., Ambohamsah, I., \& Amelia, R. (2021). Modifikasi Makanan Untuk Meningkatkan Gizi Balita Di Kabupaten Polewali Mandar. Jurnal Kesehatan Kusuma Husada, 94-102. https://doi.org/10.34035/jk.v12i1.614

Kadarhadi, E. (2012). Pengaruh Konseling Dengan "Feeding Rules" Terhadap Status Gizi Anak Dengan Kesulitan Makan [Universitas Diponegoro]. http://eprints.undip.ac.id/37514/1/ELV A_KADARHADI_G2A008141_LAP ORAN_HASIL_KTI.pdf

Kant, I., Pandelaki, A. J., \& Lampus, B. S. (2013). Gambaran Kebiasaan Makan Masyarakat di Perumahan Allandrew Permai Kelurahan Malalayang I Lingkungan XI Kota Manado. Jurnal Kedokteran Komunitas Dan Tropik, 1(3).

file:///C:/Users/User/Downloads/33236227-2-PB.pdf

Kosasih, D. (2021). Yuk, Kenali Manfaat Kandungan Gizi pada Ikan Agar Kamu tetap Sehat. https://www.gooddoctor.co.id/hidupsehat/nutrisi/kandungan-gizi-ikanyang-harus-kamu-tahu/

Kristyani, K. (2019). Panduan Pemberian MPASI 10 Bulan, Berikut kebutuhan Kalori dan Nutrisi yang Dibutuhkan Bayi Usia Ini. https://nakita.grid.id/read/021781353/ panduan-pemberian-mpasi-10-bulanberikut-kebutuhan-kalori-dan-nutrisiyang-dibutuhkan-bayi-usiaini?page $=$ all

KumparanMOM. (2020). 7 Bahan MPASI yang Baik untuk Perkembangan Tulang Bayi. https://kumparan.com/kumparanmom/ 7-bahan-mpasi-yang-baik-untukperkembangan-tulang-bayi1uAecZ7Jwhf/full

Lingga. (2019). Pelaksanaan Perencanaan Terstruktur Melalui Implementasi Keperawatan. https://osf.io/jdu $7 \mathrm{v}$

Litha, Y. (2020). UNICEF Indonesia: Pandemi Dipredksi Tingkatkan Jumlah Kasus Stunting. https://www.voaindonesia.com/a/unice f-indonesia-pandemi-diprediksitingkatkan-jumlah-kasusstunting/5485964.html

Masyudi, Mulyana, \& Rafsanjani, T. M. (2019). Dampak Pola Asuh Dan Usia Penyapihan Terhadap Status Gizi Balita Indeks Bb/U. Jurnal Action, 4(2), 111-116. file:///C:/Users/User/Downloads/174803-1-PB.pdf

Mustinda, L. (2016). Ini Alasannya, Pasien Perlu Habiskan Makanan yang Disajikan Rumah Sakit. https://food.detik.com/info-sehat/d3287006/ini-alasannya-pasien-perluhabiskan-makanan-yang-disajikanrumah-sakit

Napu, A. (2019). Status Gizi Buruk,Kurus, Stunting Dan Gemuk.

https://dinkes.gorontaloprov.go.id/stat us-gizi-buruk-kurus-stunting-dangemuk/\#: :text=Anak yang kurang gizi ada,-2SD (Riskesdas 2018)

Nareza, M. (2020). Perkembangan dan Berat Badan Bayi 10 Bulan. https://www.alodokter.com/perkemba ngan-dan-berat-badan-bayi-10-bulan

Natasha, M. (2020). Mengkonsumsi Suplemen Makanan, Apa yang Harus Diperhatikan?

https://www.sehatq.com/artikel/sebelu m-konsumsi-suplemen-makananperhatikan-hal-ini

Noya, A. B. L. (2018). Dampak Gizi Buruk Terhadap Kesehatan dan Daya Tahan Tubuh.

ttps://www.alodokter.com/dampakgizi-buruk-terhadap-kesehatan-dandaya-tahan-tubuh

Oktavia, S., Widajanti, L., \& Aruben, R. 
(2017). FAKTOR-FAKTOR YANG BERHUBUNGAN DENGAN STATUS GIZI BURUK PADA BALITA DI KOTA SEMARANG TAHUN 2017 (Studi di Rumah Pemulihan Gizi Banyumanik Kota Semarang). Jurnal Kesehatan Masyarakat (e-Journal), 5(3), 186192.

https://doi.org/https://ejournal3.undip. ac.id/index.php/jkm/article/view/1720 9. Diunduh pada tanggal 9 Maret 2021 pukul 22.10 WIB.

Pane, M. D. C. (2020). Malabsorbsi Makanan. https://www.alodokter.com/malabsorb si-makanan

PPNI, Tim Pokja SDKI DPP. (2016). Standar Diagnosis Keperawatan Indonesia. DPP PPNI.

PPNI, Tim Pokja SIKI DPP. (2018). Standar Intervensi Keperawatan Indonesia. DPP PPNI.

Puteri, A. (2020). 4 Sumber Lemak Terbaik untuk MPASI bayi. https://www.orami.co.id/magazine/le mak-untuk-mpasi-bayi/

Rachmawati, N., Pontang, G. S., \& Mulyasari, I. (2020). Acceptance Formulations Instant Breast From Soybean Tempeh As Breastfeeding For 6-12 Months Aged Babies. Jurnal Gizi Dan Kesehatan, 11(27), 1-10. file:///C:/Users/ASUS/Downloads/55Article Text-148-1-10-20200211.pdf

Rahim, F. K. (2014). FAKTOR RISIKO UNDERWEIGHT BALITA UMUR 7-59 BULAN. Jurnal Kesehatan Masyarakat, 9(02), 115-121. https://journal.unnes.ac.id/nju/index.p hp/kemas/article/view/2838/2894

Rahmawati, L. D. (2011). Rambut Kering: Gejala Penyakit Serius. https://www.fimela.com/beautyhealth/read/3704078/rambut-keringgejala-penyakit-serius

RI, K. K. (2018). Khasiat dan Manfaat Pisang. http://www.p2ptm.kemkes.go.id/artike l-sehat/khasiat-dan-manfaat-pisang
Riadi, M. (2012). Perawatan rongga Mulut (Oral Hygiene).

https://www.kajianpustaka.com/2012/ 11/perawatan-rongga-mulut-oralhygiene.html

Riadi, M. (2019). Fungsi, Aspek dan Jenisjenis Diet. https://www.kajianpustaka.com/2019/ 08/fungsi-aspek-dan-jenis-jenisdiet.html

Safira, N. (2019). Konsep Perencanaan Keperawatan.

https://osf.io/preprints/inarxiv/ch6mz/

Sampul, M. P. K., Ismanto, A. Y., \& Pondaag, L. (2015). HUBUNGAN DIARE DENGAN KEJADIAN MALNUTRISI PADA BALITA DI IRINA E BAWAH RSUP PROF. Dr. R. D. KANDOU MANADO. Ejournal Keperawatan (e-Kp), 3(1), 1-7. https://doi.org/https://ejournal.unsrat.a c.id/index.php/jkp/article/view/6689/6 209. Diunduh pada tanggal 5 Maret 2021 pukul 21.00 WIB

Sandi, F. (2013). Pengaruh Pelatihan Terhadap Keterampilan Kader Dalam Pembuatan Pmt Modisco Di Wilayah Kerja Puskesmas Pematang Panjang Kecamatan Air Putih Kabupaten Batubara Tahun 2012 [Universitas Sumatera Utara]. https://minio1.123dok.com/dt03pdf/12 3dok/000/022/22676.pdf.pdf?X-AmzContent-Sha256=UNSIGNEDPAYLOAD\&X-AmzAlgorithm=AWS4-HMACSHA256\&X-AmzCredential=HBT28R878GBP52A279 VA\%2F20210618\%2F\%2Fs3\%2Faws 4_request\&X-AmzDate $=20210618$ T063406Z\&X-AmzSignedHeaders $=$ host $\& X-A m z-$ Expires $=600 \& X-A m z-$ Signature $=a e 6 b 39 a 8 e 77 a 3 f 6 f c 7703 b 7$ 4b2f603f97b4e4744c2ca3e3f73e9a06c $0485 \mathrm{a} 5 \mathrm{e} 6$

Saraswati, R. (2020). Mengenal Marasmus, Malnutrisi yang Mengancam Nyama Anak.

https://www.sehatq.com/artikel/menge 
nal-marasmus-malnutrisi-pada-anakyang-mengancam-nyawa

Sari, I. Y. (2020). Panduan Perkembangan Bayi 10 Bulan yang Normal Terjadi, Mulai dari Berat Badan Sampai Komunikasi Si Kecil. https://nakita.grid.id/read/021999949/ panduan-perkembangan-bayi-10bulan-yang-normal-terjadi-mulai-dariberat-badan-sampai-komunikasi-sikecil?page $=$ all

Sera. (2020). Ternyata Anoreksia Bisa Terjadi pada Bayi, Waspada ya Moms!

https://www.orami.co.id/magazine/ano reksia-pada-bayi/

Setiaputri, K. A. (2021). Berat Badan Kurang (underweight) pada Anak, Bagaimana Mengetahuinya? https://hellosehat.com/parenting/keseh atan-anak/malnutrisi/anakunderweight-berat-badan-kurang/

Sholikah, A., Rustiana, E. R., \& Yuniastuti, A. (2017). Faktor - Faktor yang Berhubungan dengan Status Gizi Balita di Pedesaan dan Perkotaan. Public Health Perspective Journal, 2(1), 9-18. https://doi.org/https://journal.unnes.ac. id/nju/index.php/phpj/article/view/109 93. Diunduh pada tanggal 9 Maret 2021 pukul 22.00 WIB.

Sutrio, S., Rahmadi, A., Putri, S., Sumardilah, D. S., Mulyani, R., Lupiana, M., \& Indriyani, R. (2021). Edukasi Gizi dan Pemberian Bantuan Kepada Keluarga Balita Gizi Kurang Terdampak Covid-19 di Kelurahan Kedaung Kota Bandar Lampung. Jurnal Pengabdian Masyarakat Indonesia, 1(2), 43-48. https://doi.org/10.52436/1.jpmi.7

Swari, R. C. (2020). 10 Makanan Lezat yang Mengandung Protein Tinggi. https://hellosehat.com/nutrisi/faktagizi/10-makanan-sumber-proteintinggi/

Tanhati, S. (2018). Mama Wajib Tahu! Pentingnya Membersihkan Lidah dan Mulut Bayi. https://www.popmama.com/baby/0-6months/sysilia-tanhati/pentingnyamembersihkan-lidah-dan-mulut-bayi/4

Temanggung, D. K. (2018). Profil Kesehatan Kabupaten Temanggung Tahun 2018. https://dinkes.temanggungkab.go.id/as sets/file/190826052040.pdf

Tengah, D. K. J. (2019). Profil Kesehatan Provinsi Jawa Tengah 2019. file://C:/Users/User/Downloads/Profil -Jateng-tahun-2019.pdf

Utama, H., \& Herqutanto. (2014). Penuntun Diet Anak (Edisi ke 3). Fakultas Kedokteran Universitas Indonesia.

Wiliam. (2021). Ternyata Tempe Bisa Mengobati Diare pada Anak. https://www.guesehat.com/tempebisa-mengobati-diare-pada-anak Yuniar, M. (2019). 8 Manfaat Telur Bagi Kesehatan Tubuha yang Belum Anda Ketahui. https://www.sehatq.com/artikel/8manfaat-telur-bagi-kesehatan-tubuhyang-belum-anda-ketahui 